\title{
Rare events in the Arctic
}

\author{
James E. Overland ${ }^{1}$
}

Received: 1 July 2021 / Accepted: 2 October 2021 / Published online: 27 October 2021

This is a U.S. government work and not under copyright protection in the U.S.; foreign copyright protection may apply 2021

\begin{abstract}
Twenty years ago, the Arctic was more resilient than now as sea ice was three times thicker than today. Heavier and more persistent sea ice provided a buffer against the influence of short-term climate fluctuations. Sea ice/atmospheric interactions now point to revisiting the concept of abrupt change. The recent decade has seen Arctic extreme events in climate and ecosystems including some events beyond previous records that imply increased future uncertaintly. While their numbers may increase, the distribution of the type, location, and timing of extreme events are less predictable. Recent processes include albedo shifts and increased sensitivity of sea ice to storms in marginal seas. Such new extremes include Greenland ice mass loss, sea ice as thin and mobile, coastal erosion, springtime snow loss, permafrost thaw, wildfires, and bottom to top ecosystem reorganizations, a consilience of impacts. One cause for such events is due to natural variability in a wavy tropospheric jet stream and polar vortex displacements, interacting with ongoing Arctic Amplification: temperature increases, sea ice loss, and permafrost thaw. This connecting hypothesis is validated by the variability of rare events matching interannual and spatial variability of weather. A proposed way forward for adaptation planning is through narrative/scenario approaches. Unless $\mathrm{CO}_{2}$ emissions are reduced, further multiple types of Arctic extremes are expected in the next decades with environmental and societal impacts spreading through the Arctic and beyond.
\end{abstract}

Keywords Arctic change $\cdot$ Sea ice $\cdot$ Global warming $\cdot$ Polar vortex $\cdot$ Greenland $\cdot$ Extreme events

\section{Introduction}

In the last few years, there are extreme events, some beyond previous limits, such as wildfires in Siberia, loss of ice and snow in Greenland, and subarctic/midlatitude impacts such as ecosystem/fishery impacts in the Bering Sea and snow storms in Texas. They are often record-shattering (Fisher et al. 2021). Such extremes vary in type, location, timing, and

James E. Overland

james.e.overland@noaa.gov

1 Pacific Marine Environmental Laboratory, National Oceanic and Atmospheric Administration, Seattle, WA, USA 
Fig. 1 Causal network for discussion of new ecosystem impacts. Arrows indicate direction of causal influence. The blue shading indicates elements whose causality lies in the weather and climate domain, the purple shading those in the ecosystem domain, and the orange shading a combination of multiple causation

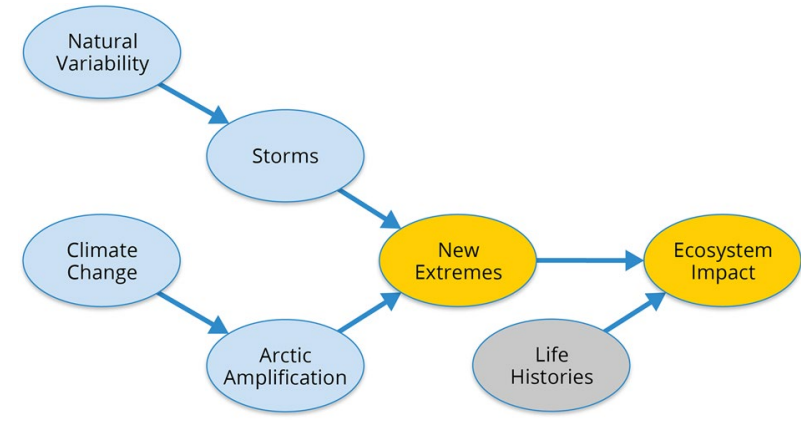

duration. Taken together, these multiple extremes are an indicator of rapid Arctic change relative to trends in single variables such as increasing temperatures. Moon et al. (2019) note the expanding footprint of rapid Arctic change. Landrum and Holland (2020) from models show anthropogenically forced emergence of sea ice and surface temperatures from internal variability, and conclude that the Arctic is already transitioning from a cryospheredominated system. However, there is not necessarily a major shift in atmospheric circulation such as noted in the Arctic Oscillation and regional statistics, as wind patterns have a large range of natural variability. Arctic changes such as temperature increases, permafrost thaw, and sea ice loss, noted as Arctic Apmplification (AA), are providing precursor conditions that combine with the natural range of atmospheric circulation to result in extreme impacts as shown by Fig. 1. That new impacts do not require circulation deviations to be much beyond their normal range suggests a reason for the large number of impacts and interannual variability of events in recent years. The conceptual model in Fig. 1 hypothesizes global warming from $\mathrm{CO}_{2}$ increases has a thermodynamic response in AA, and combines with the natural range of atmospheric dynamics, i.e., jet stream and storms. This provides a large range of Arctic and subarctic extreme event types and temporal variability. These physical extremes selectively influence ecosystems based on species-specific life history, such as critical timing of reproduction and migration. Societal impacts follow directly from sea ice and ecosystem shifts.

The goal of this paper is to propose that the extreme events that are happening are due to changing Arctic conditions (sea ice, temperatures) interacting with atmospheric variability on weather-related time and space scales. It hypothesizes that Arctic change is manifested in weather-related extremes in addition to trends of projected temperatures $\left(0.8{ }^{\circ} \mathrm{C}\right.$ per decade, https://www.arctic.noaa.gov/Report-Card). Several recent examples are presented including sea ice loss/ecosystems impacts in the Bering and Barents Seas, Greenland ice mass loss, and coastal erosion, noting their tie to atmospheric circulation variability. Taken together, current extreme events provide a consilience for ongoing Arctic change. These types of extremes are introducing more uncertainty for planning purposes and that more traditional methods of risk assessment and decision-making (e.g., forecasts made on frequency and probability statistics) are inadequate, and suggest that a different approach to decision-making due to the nature of these extremes could be applied.

How does one interpret events at or beyond previous experience? A classic method is based on fitting data to a frequency approach with a probability distribution such as a Gaussian or long tail model. These backward-looking risk assessments extrapolate historical trends. However, one cannot enumerate the states of nature that will arise much less assign them probabilities. Climate models are good at showing the linear increase in Arctic-wide temperatures but do not always handle the interaction of multiple regionl 
processes (Cohen et al. 2020; Smith et al. 2020). An alternate approach is to admit that the new observations may have different underlying physics than a historical model. The simplest way of acknowledging this approach is if there is additional information that the process may be non-stationary or that the event may be considered previously unimaginable prior to the event. To recommend action, one cannot wait and learn more about fixed processes. The magnitude of future events is uncertain with unpredictable consequences (Fisher et al. 2021). Events for whose processes are insufficiently understood for deterministic forecasts or for probabilities to be known have been labelled radical uncertainty (Kay and King 2020). In the Arctic, uncertainty results from multiple sources including extreme events.

\section{Loss of sea ice as precursor}

A major precursor of further Arctic impacts is loss of sea ice. Over the last 15 years, sea ice is reduced in both areal extent (40\% in summer) and in thickness. Old multi-year sea ice (sea ice maintained for multiple years) has thinned from mostly $3 \mathrm{~m}$ thickness to new first year formed sea ice of less than a meter (Schweiger et al. 2019, as updated by PIOMAS). January 2021 total Arctic sea ice volume was the second-lowest on record after 2017. Sea ice is thinner, more variable than previously thought (Mallet et al. 2021, Schweiger et al. 2021).

The effect of thinning sea ice in 2018 was shown by the unusual meteorological event that caught the public's attention with reports of wintertime temperatures warming to near the freezing point at the North Pole. Several recent Arctic warm events such as 25 February 2018 (Fig. 2) were caused by advection of heat and moisture into the Arctic across the thinning marginal sea ice zone and newly open water on an Atlantic atmospheric pathway. Northward warm/moist temperature advection increases downward long wave radiation, delayed sea ice freeze-up along the trajectory, and thus provides a positive feedback that maintained record high temperature events (Binder et al. 2017; Cullather et al. 2016; Kim et al. 2017; Rinke et al. 2017).

Another sea ice/weather interaction was the Bering Sea in winters of 2018 and 2019. The Bering Sea historically grows sea ice from November through March through freezing and advection of ice southward by northerly winds. Such a pattern was broken during 2018 and 2019 (Fig. 3) with a decrease in ice area into February and March. Such regional sea ice loss events were related to an unusual southwest-northeast orientation of the jet stream (Overland 2020). The year 2019 was the first time in the 53-year record of hydrographic profiles beginning 1966 on the Bering Sea shelf that show 6 years in a row of higher-thanaverage temperatures on the continental shelf (Danielson, personal communication, 2020).

The risk of ecosystem reorganization is high for the Bering Sea (Britt et al. 2019; DuffyAnderson et al. 2019). In previous "normal" years, the southward advance of sea ice established a bottom layer ocean cold pool, because of increased upper ocean stratification due to sea ice melt. The cold pool favored preferred prey for the large pollock fishery and was lacking in 2018 and 2019 (Stabeno and Bell 2019; Eisner et al. 2020). Pacific cod moved north, ice-dependent seals and walrus lost their platform for resting and breeding, there have been warm water-driven toxic algae blooms, and seabird die offs (Gay Sheffield 2020, personal communication). The occurrence of sea ice loss in 2018 and 2019 is earlier than projected by models (Wang et al. 2018). One should not be surprised to see such future environmental shocks in some years during the next decade (Thoman et al. 2020). The 


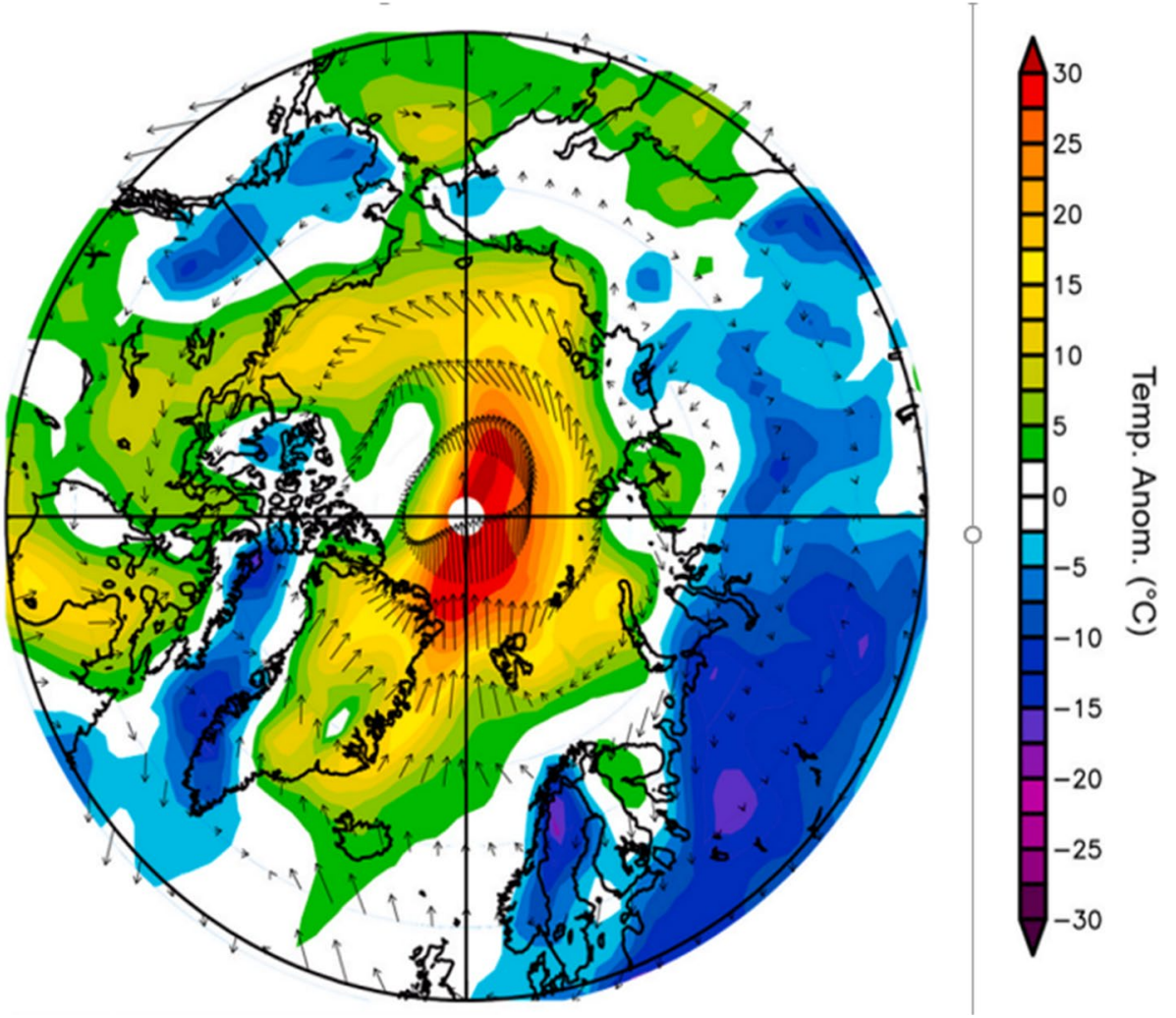

Fig. 2 Composite $2 \mathrm{~m}$ air temperature anomaly (1981-2010 baseline) and $1000 \mathrm{hPa}$ vector winds on 25 February 2018. Winds favorable to warm advection are associated with warm temperature anomalies of $15-30{ }^{\circ} \mathrm{C}$. Temperatures at Cape Jessup, northern Greenland, were $+6{ }^{\circ} \mathrm{C}$. Data from the NCEP/NCAR Reanalysis

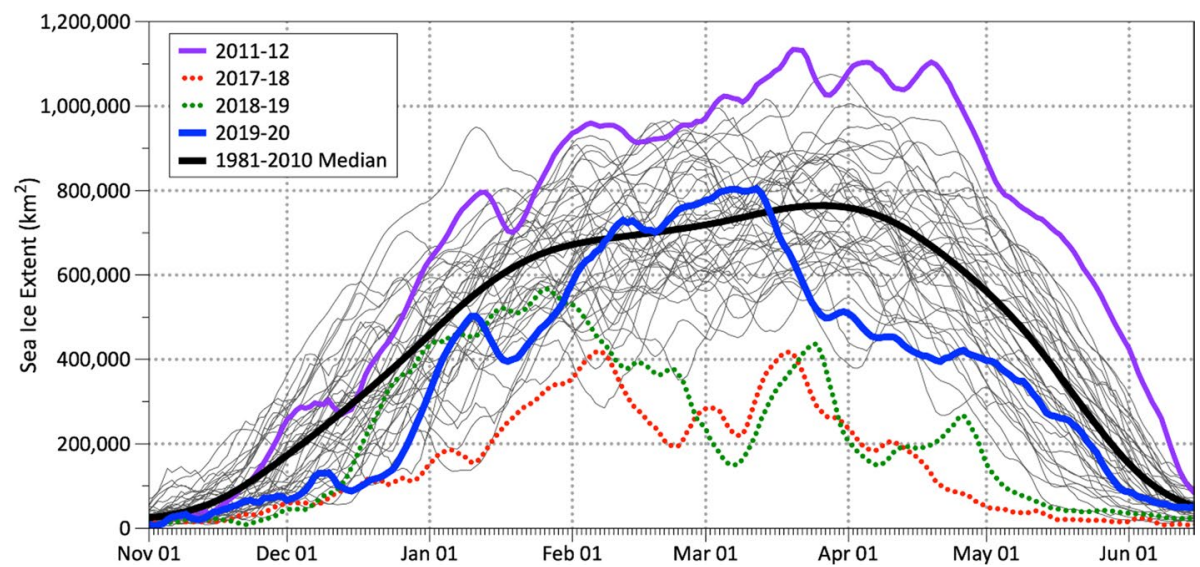

Fig. 3 Winter sea ice evolution in the Bering Sea. Low sea ice occurs in winter 2018 and 2019. From R. Thoman, 2020, personal communication, data from National Snow and Ice Data Center (NSIDC) 


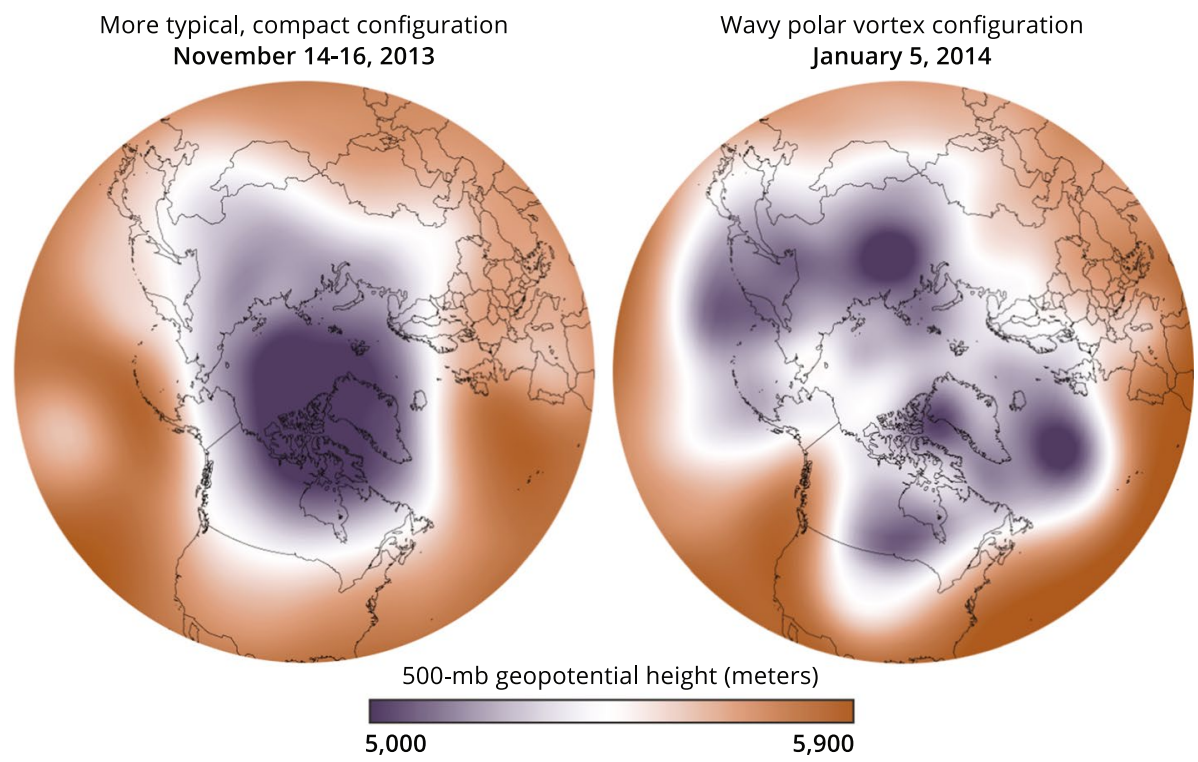

Fig. 4 Contrasting geopotential height fields at the lower jet stream level $(500 \mathrm{hPa})$ with low values in purple and the jet stream in white. a A single and more west to east jet stream encircling the pole that contrasts with a wavier configuration (b) with multiple low height centers (dark purple). Figure from NOAA Climate. gov

Barents Sea has reached a "tipping point" (Lind et al. 2018); loss of sea ice shifted the Barents Sea from acting as a buffer between the Atlantic and Arctic oceans to something closer to an arm of the Atlantic. Subarctic fisheries are vulnerable to ecosystem reorganization in the Bering and Barents Seas (Griffith et al. 2019; Isaksen et al. 2016; Lone et al. 2019).

I now provide a background section on atmospheric variability.

\section{Circulation variability: features of Northern Hemisphere weather}

Recent studies have found that weather connectivity between Arctic and midlatitude depends not only on the magnitude of Arctic temperature amplification, but also on the location, amplitude, and movement of meanders in the polar jet stream. Figure 4 shows that the jet stream (a band of stronger winds - shown in white-halfway up in the atmosphere) can have more than one manifestation such as an elliptical zonal (west-east) configuration (left) or a wavier shape (right). The wavy configuration moves warm air to the north and cold air to the south, depending on the longitudinal locations of the wavy structure. Excursions to the north are ridges as they are associated with high pressure, and those to the south are troughs as they are associated with low pressure, and often severe weather. While Arctic Amplification is ongoing every year, potential linkages between the Arctic and subarctic/midlatitude weather depend on the variability and configuration of the jet stream in the mid/upper troposphere (5-10 km altitude) and the stratospheric polar vortex (SPV; at $15-40 \mathrm{~km}$ altitude).

That jet stream excursions shift both temporally and in terms of their longitudinal location argues for the potential weather linkages occurring irregularly, i.e., lack of 
trend or cycle on an annual or seasonal basis, despite continued Arctic Amplification. Inspection of year-to-year variability (e.g., Kug et al. 2015) shows such irregularity. Amplified Arctic warming in early winter may not in itself initiate midlatitude connections, but instead intensify such interactions by enhancing the amplitude of existing large-scale jet stream excursions and therefore contribute to the establishment of stationary atmospheric wind patterns known as blocking (Woollings et al. 2018; Tachibana et al. 2019; Luo et al. 2019; Overland et al. 2021). Although the range of natural variation in storms is emphasized, there are some suggestions of recent changes in storm tracks and intensity (Villamil-Otero et al 2018).

We thus can partition the causation of new extremes into four parts as in Table 1 and Fig. 1: external forcing from $\mathrm{CO}_{2}$ increases and global temperatures, precursor forcing from steady changes in Arctic temperatures and sea ice loss, random forcing from large weather events, and impacts from the collective action of multiple forcing, examples to follow.

\section{Greenland ice mass loss}

Unprecedented atmospheric conditions (1948-2019) occurring in the summer of 2019 over Greenland promoted new record or close-to-record values of surface mass balance, runoff, and snowfall (Tedesco and Fettweis 2020). The summer of 2019 was characterized by an exceptional persistence of southerly wind conditions that, in conjunction with low albedo associated with reduced snowfall in summer, promoted the absorption of solar radiation and favored advection of warm, moist air along the western side of the Greenland ice sheet. This event is summarized by Fig. 5, which shows the historical relation between Greenland ice loss (based on runoff) and high atmospheric pressure leading to southerly winds on the west coast of Greenland. While there is a long-term downward trend in Greenland ice mass, the major loss years are associated with single

Table 1 Hierarchical climate forcing in the Arctic

\begin{tabular}{lll}
\hline Type & Variable & Occurrence \\
\hline External forcing & $\mathrm{CO}_{2}$, temperature $^{1}$ & Continuing, Annual 2018, 2020 \\
Precursor forcing & Sea ice loss $^{2}$ & September 2020, January 2021 \\
Random forcing & Atmospheric circulation $^{3}$ & $2018,2019,2020$ \\
Impacts & Greenland ice sheet mass loss $^{4}$ & 2019 \\
& Permafrost thaw $^{5}$ & Alaska, Alert, Svalbard 2019 \\
& Wildfires $^{6}$ & Alaska 2019, Siberia 2020 \\
& Snow $^{7}$ & May-June 2019 \\
& Coastal erosion $^{8}$ & north Alaska 2020 \\
& Marine ecosystems $^{9}$ & Bering Sea 2018, 2019, Barents \\
& & Sea 2010-2019 \\
\hline
\end{tabular}

Sources: ${ }^{1}$ Reporting on the State of the Climate in 2020 । NOAA Climate.gov, ${ }^{2}$ Schweiger et al. (2021), ${ }^{3}$ Overland et a. (2021), ${ }^{4}$ Tedesco \& Fettweis (2020), ${ }^{5}$ Romanovsky et al.(2020), ${ }^{6}$ Kim et al. (2020), ${ }^{7}$ Meredith et al. (2019), ${ }^{8}$ Walsh et al. (2020), ${ }^{9}$ Duffy-Anderson (2019) 


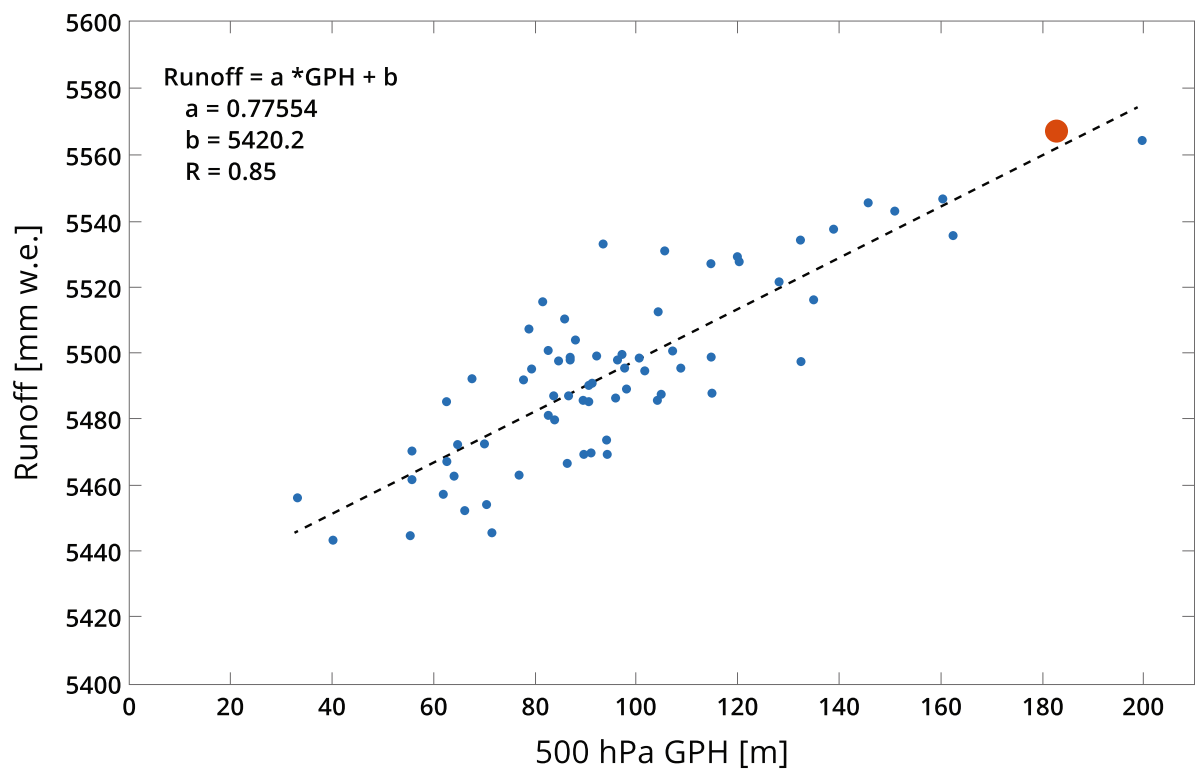

Fig. 5 Scatterplot between Greenland runoff $(\mathrm{mm})$ and $500 \mathrm{hPa}$ geopotential height (m) for 1948-2019. Red disk shows 2019 value. Domain is $60-80^{\circ} \mathrm{N}, 20-80^{\circ} \mathrm{W}$. From Tedesco and Fettweis (2020)

events when the jet stream lines up with ridging over central Greenland (J. Box and E. Hanna, personal communication, 2021).

\section{Other impact examples}

Permafrost is frozen ground made up of soil, organic material, and ice. Permafrost thaw is particularly relevant for climate change as it is an irreversible process; thawing also releases methane. Recent large melt events are Arctic-wide including coastal Alaska, northeastern Canada (Alert), and Svalbard with temperature increases of $1.5-2.0{ }^{\circ} \mathrm{C}$ since 2000; at the lowest permafrost temperature sites, the twenty-first-century warming rates have been the greatest on record (Romanovsky et al. 2020).

Wildfires are associated with early snowmelt exposing the land surface to evapotranspiration that promotes drier ground conditions and the spreading of boreal fires (Kim et al. 2020). Recent severe fire outbreaks in Russia and Fennoscandia during 2018 and 2020 and Alaska during 2015 and 2019 highlight these impacts with large interannual variability (Fig. 6). Peak burned area years correspond with extremely warm season air temperatures and high winds. Wildfires thus have a temporally sporadic and non-linear character.

Major loss of snow cover extent is for May through June (Meredith et al. 2019). The estimated reduction over the 1971-2019 period for the Eurasian Arctic is - 25\% and for the North American Arctic is $-17 \%$ (Box et al. 2019, updated). Such springtime snow cover shows considerable year-to-year differences and variability between continents, suggesting regional meteorological origin. 


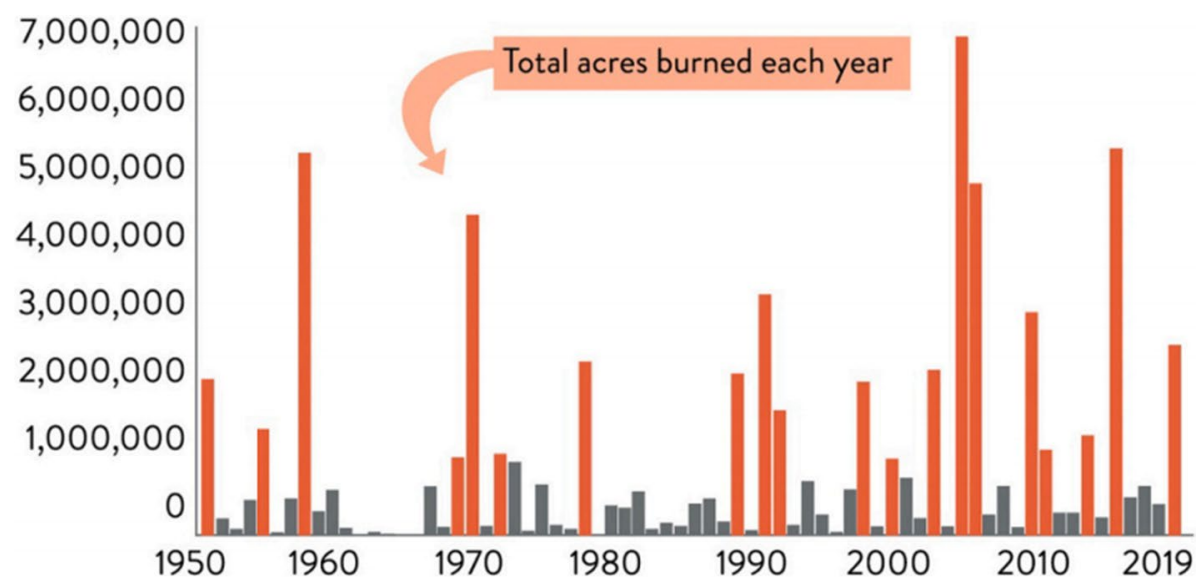

Fig. 6 Yearly numbers of acres burned by wildfires in Alaska, 1950-2019. Wildfire seasons with more than one million acres burned (red bars in graph) have increased by 50\% since 1990, compared to 1950-1989. Source: Thoman and Walsh (2019)

Coastal erosion is one of the more visible manifestations of extreme weather and climate events in northern regions. Coastal erosion rates in the Arctic are indeed among the largest on the earth, with average rates of retreat of several meters per year along much of the Russian and Alaskan coasts (Walsh et al. 2020). Various studies have pointed to a doubling of coastal erosion rates in the Arctic in recent decades (Frederick et al. 2016; Rolph et al. 2018). Increased rates of coastal erosion in the Arctic are due to recent loss of sea ice in combination with Arctic storm activity, a longer open water season, warmer water and air temperatures, and especially increased fetch for wave buildup during storms.

\section{Weather-driven extremes}

The proximate cause of the 2018 and 2019 Bering Sea events was the movement of the stratospheric polar vortex and the tropospheric jet stream off its more normal center over the North Pole to a location over Greenland (Overland et al. 2021). Winters 2018 and 2019 showed wavy jet stream pattern with warm air temperature advection into the northern Bering Sea (Fig. 7a). More typical years, such as 2017 and before and 2020, had a more west-to-east zonal jet stream pattern located to the south of Alaska, allowing a more climatological winter sea ice growth in the Bering Sea. The movement of the jet stream is considered chaotic and random, despite Arctic changes (Woollings et al. 2018). Thus, the combined thinning of sea ice and chaotic weather extremes provided a new overall sea ice loss and ecosystem reorganization mechanism in the Bering Sea.

The wavy jet stream is not the only meteorological pattern that can influence midlatitude weather extremes. The winter-spring (January-April) 2020 Siberian heat wave (record Arctic temperature of $38{ }^{\circ} \mathrm{C}$ ) with extensive wildfires resulted from the more southerly zonal location of the jet stream that reduced the potential penetration of cold air from the north (Fig. 7b). Another example of a southern location of a strong zonal type jet stream 
a

NCEP/NCAR Reanalysis

$700 \mathrm{mb}$ Geopotential Height $(\mathrm{m})$ Composite Mean

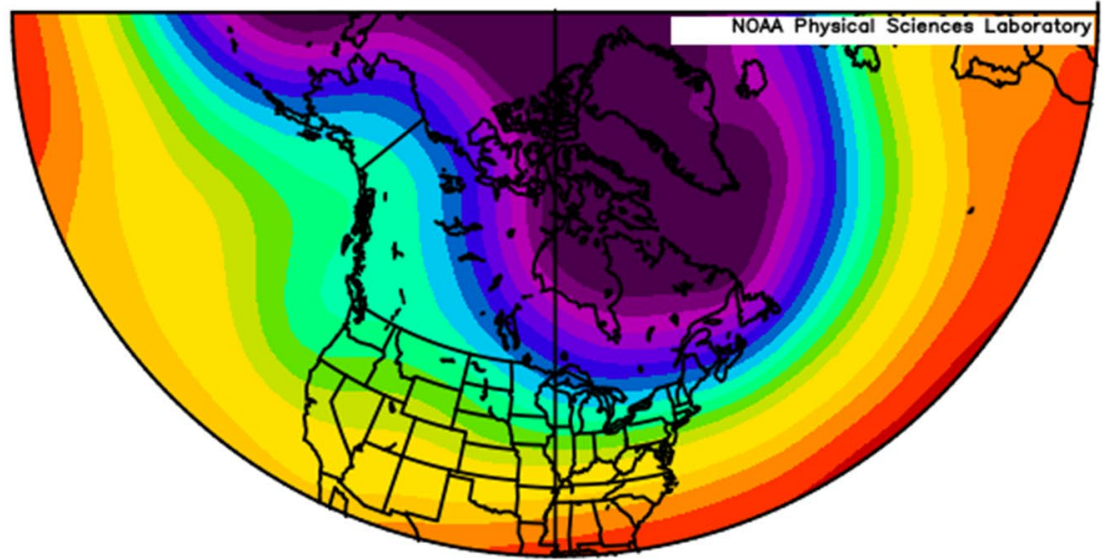

Feb to Mar: 2019

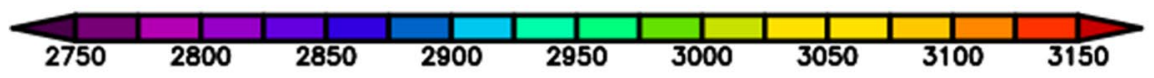

b

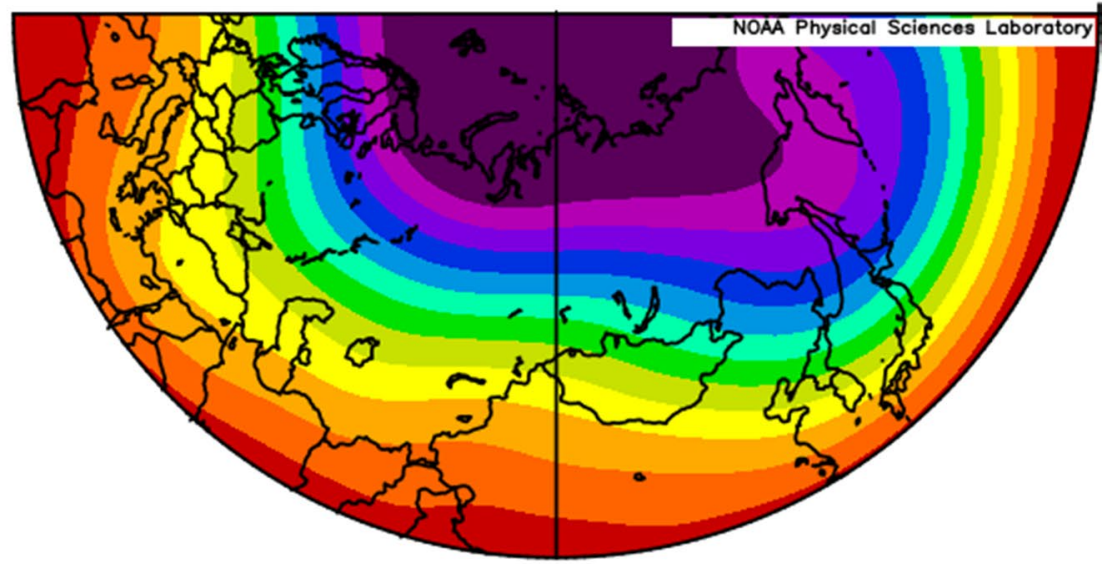

Jan to Apr: 2020

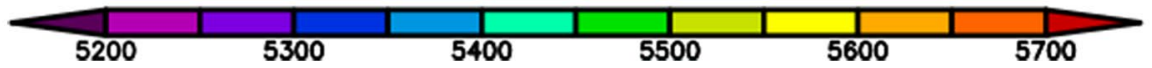

Fig. 7 a $700 \mathrm{mb}$ geopotential height for February-March 2019 showing a wavy jet stream (purple/blue) that supported southerly winds and no sea ice growth in the Bering Sea. b $500 \mathrm{mb}$ level of the jet stream for January-April 2020 over Siberia showing the strong winds and southerly location. NCEP/NCAR Reanalysis data plotted from NOAA ESRL/PSD website 
impact was the cold temperatures and snow over Texas, USA, during mid-February 2021. Due to poor weather and loss of power, there was loss of 80 lives with this event. The Texas event was short lived as the severe weather moved rapidly east-northeast with the strong jet stream. These extreme weather events are noteworthy with Arctic conditions reaching into the subarctic and midlatitudes, but are not necessarily caused by AA and often have historical analogues.

\section{Conclusions}

In 2020, there were 22 separate billion-dollar weather and climate disasters across the USA, shattering the previous annual record of 16 events, which occurred in 2017 and 2011 (www.ncdc.noaa.gov/billions). Although there is not clear frequency information for the Arctic, the list in Table 1 over 2018-2020 is an impressive consilience, especially for the range of types of extremes.

Climate-related future impacts will remain largely unhedgeable. The solution is an adaptation strategy rather than a forecast. Such an alternate approach, decision making under deep uncertainty, was mentioned in the IPCC SROCC (IPCC 2019). The increase in future uncertainty due to lack of event extrapolation does not mean that planning is less important. A recent alternative in climate change policy is by the practice of decision making under deep uncertainty (DMDU) (Shortridge et al. 2017). The approach is an adaptive method, defining specific risks, policy objectives, and evaluation criteria (Lloyd and Shepherd 2020). Causal factors for Arctic impacts combine weather (jet stream and storms) and global change-driven Arctic Amplification (temperature, sea ice, permafrost), such as diagrammed in Fig. 1. An example of potential ecosystem impacts are on sea ice-dependent walrus and ribbon seals in the northern Bering and Chukchi Seas. Walrus forage from ice floes on the ocean bottom for clams, and ribbon seals require ice floes for pupping and nursing in April-May and molting in May-June. Without sea ice, walrus haul out on shore locations, and thus have longer travel distance and lower foraging efficiency (Jay et al. 2017). On a decadal time scale, sea ice is thinning and becoming more broken. Major loss years, however, occur with strong southerly wind events, which do not occur every year (Fig. 3). While historically populations can survive several unfavorable years per decade, an increase in frequency of adverse events could affect the sustaining of their populations (Boveng et al. 2013; Wang et al. 2018). Implementation of an adaptation plan by NOAA involves organized monitoring and modification as new information becomes available.

A decade ago, one would consider the events in Table 1 as surprises; now, they are expected but individually uncertain in type, location, timing, and duration. What is new is that the normal range of weather events are interacting with steady Arctic climate change of temperature increases and sea ice loss to produce an increased frequency of Arctic extreme events and ecosystem impacts (Fig. 1, Table 1). Evidence for changes in frequency of storm events in northern regions is limited, although change in intensity is possible due to more heat absorption in newly open water areas (Walsh et al. 2020). One example of extreme events is the year-to-year variation in wildfires, combining increased temperatures and dryness with spring and summer weather events. Another example is coastal erosion, with newly open water increasing wave fetch during storms. The consilience of recent extreme events should spur action. 
Open Access This article is licensed under a Creative Commons Attribution 4.0 International License, which permits use, sharing, adaptation, distribution and reproduction in any medium or format, as long as you give appropriate credit to the original author(s) and the source, provide a link to the Creative Commons licence, and indicate if changes were made. The images or other third party material in this article are included in the article's Creative Commons licence, unless indicated otherwise in a credit line to the material. If material is not included in the article's Creative Commons licence and your intended use is not permitted by statutory regulation or exceeds the permitted use, you will need to obtain permission directly from the copyright holder. To view a copy of this licence, visit http://creativecommons.org/licenses/by/4.0/.

\section{References}

Binder H, Boettcher M, Grams CM, Joos H, Pfahl S, Wernli H (2017) Exceptional air mass transport and dynamical drivers of an extreme wintertime Arctic warm event. Geophys Res Lett 44:12028-12036. https://doi.org/10.1002/2017GL075841

Boveng PL, Bengtson JL, Cameron MF, Dahle SP, Logerwell EA, London JM et al (2013) Status review of the ribbon seal (Histriophoca fasciata). NMFS-AFSC-255, US Dep Commer, NOAA Tech Memo, 174 pp

Box JE, Colgan WT, Christensen TR, Schmidt NM, Lund M, Parmentier F-JW et al (2019) Key indicators of Arctic climate change: 1971-2017. Environ Res Lett 14(4):045010. https://doi.org/10.1088/17489326/aafc1b

Britt L, Dawson L, Haehn R, Stevenson D (2019) Northern Bering Sea groundfish and crab trawl survey highlights. NOAA Alaska Fisheries Science Center.

Cohen J, Zhang X, Francis J, Jung T, Kwok R, Overland J et al (2020) Divergent consensuses on Arctic amplification influence on midlatitude severe winter weather. Nat Clim Change 10:20-29. https://doi. org/10.1038/s41558-019-0662-y

Cullather RI, Lim Y-K, Boisvert LN, Brucker L, Lee JN, Nowicki SMJ (2016) Analysis of the warmest Arctic winter, 2015-2016. Geophys Res Lett 43:10808-10816. https://doi.org/10.1002/2016GL071228

Duffy-Anderson JT, Stabeno PJ, Andrews A, Eisner LB, Farley EV, Harpold CE et al (2017) Return of warm conditions in the southeastern Bering Sea: Phytoplankton to fish. PLoS ONE 12(6):e0178955. https:// doi.org/10.1371/journal.pone.0178955

Duffy-Anderson JT, Stabeno P, Andrews AG III, Cieciel K, Deary A, Farley E et al (2019) Responses of the northern Bering Sea and southeastern Bering Sea pelagic ecosystems following record-breaking low winter sea ice. Geophys Res Lett 46:9833-9842. https://doi.org/10.1029/2019GL083396

Eisner LB, Yasumiishi EM, Andrews AG III, O'Leary CA (2020) Large copepods as leading indicators of walleye pollock recruitment in the southeastern Bering Sea: Sample-based and spatio-temporal model (VAST) results. Fish Res 232:105720. https://doi.org/10.1016/j.fishres.2020.105720

Fischer E, Sippel S, Knutti R (2021). Increasing probability of record-shattering climate extremes. Nature Climate Change. 11. https://doi.org/10.1038/s41558-021-01092-9

Frederick JM., Thomas MA, Bull DL, Jones CA, Roberts JD (2016) The Arctic coastal erosion problem. Report SAND2016-9762, Sandia National Laboratories, Albuquerque, NM

Griffith GP, Hop H, Vihtakari M, Wold A, Kalhagen K, Gabrielsen GW (2019) Ecological resilience of Arctic marine food webs to climate change. Nat Clim Change 9:868-872. https://doi.org/10.1038/ s41558-019-0601-y

IPCC (2019) Pörtner H-O, Roberts DC, Masson-Delmotte V, Zhai P, Tignor M, Poloczanska E et al (eds) IPCC special report on the ocean and cryosphere in a changing climate. The Intergovernmental Panel on Climate Change, in press. https://www.ipcc.ch/srocc/. Accessed 2020

Isaksen K, Nordli Ø, Førland EJ, Łupikasza E, Eastwood S, Niedźwiedź T (2016) Recent warming on Spitsbergen-Influence of atmospheric circulation and sea ice cover. J Geophys Res Atmos 121(20):1191311931. https://doi.org/10.1002/2016JD025606

Jay CV, Taylor RL, Fischbach AS, Udevitz MS, Beatty WS (2017) Walrus haul-out and in water activity levels relative to sea ice availability in the Chukchi Sea. J Mammal 98(2):386-396. https://doi.org/10. 1093/jmammal/gyw195

Kay J, King M (2020) Radical uncertainty. Norton and Company, New York

Kim B-M, Hong J-Y, Jun S-Y, Zhang X, Kwon H, Kim S-J et al (2017) Major cause of unprecedented Arctic warming in January 2016: critical role of an Atlantic windstorm. Sci Rep 7:40051. https://doi.org/10. $1038 /$ srep40051 
Kim J-S, Kug J-S, Jeong S-J, Park H, Schaepman-Strub G (2020) Extensive fires in southeastern Siberian permafrost linked to preceding Arctic Oscillation. Sci Adv 6(2):eaax3308. https://doi.org/10.1126/sciadv.aax3308

Kug J-S, Jeong J-H, Jang Y-S, Kim B-M, Folland CK, Min S-K, Son S-W (2015) Two distinct influences of Arctic warming on cold winters over North America and East Asia. Nat Geosci 8:759-762. https://doi. org/10.1038/ngeo 2517

Landrum L, Holland MM (2020) Extremes become routine in an emerging new Arctic. Nat Clim Change 10:1108-1115. https://doi.org/10.1038/s41558-020-0892-z

Lind S, Ingvaldsen R, Furevik T (2018) Arctic warming hotspot in the northern Barents Sea linked to declining sea-ice import. Nat Clim Change 8:634-639. https://doi.org/10.1038/s41558-018-0205-y

Lloyd EA, Shepherd TG (2020) Environmental catastrophes, climate change, and attribution. Ann NY Acad Sci 1469:105-124. https://doi.org/10.1111/nyas.14308

Lone K, Hamilton CD, Aars J, Lydersen C, Kovacs KM (2019) Summer habitat selection by ringed seals (Pusa hispida) in the drifting sea ice of the northern Barents Sea. Polar Res 38:3483. https://doi.org/ 10.33265/polar.v38.3483

Luo D, Chen X, Overland J, Simmonds I, Wu Y, Zhang P (2019) Weakened potential vorticity barrier linked to Arctic sea-ice loss and increased mid-latitude cold extremes. J Clim 32:4235-4261. https://doi.org/ 10.1175/JCLI-D-18-0449.1

Mallett RDC, Stroeve J et al (2021) Faster decline and higher variability in the sea ice thickness of the marginal Arctic seas when accounting for dynamic snow cover. Cryosphere 15:2429-2450. https://doi.org/ 10.5194/tc-15-2429-2021

Meredith M, Sommerkorn M, Cassotta S, Derksen C, Ekaykin A, Hollowed A et al (2019) Polar regions. In: Pörtner H-O, Roberts DC, Masson-Delmotte V, Zhai P, Tignor M, Poloczanska E et al (eds) IPCC special report on the ocean and cryosphere in a changing climate. The Intergovernmental Panel on Climate Change, in press. https://www.ipcc.ch/srocc/. Accessed 2020

Moon TA, Overeem I, Druckenmiller M et al (2019) The expanding footprint of rapid Arctic change. Earths Future 7:212-218

Overland JE (2020) Less climatic resilience in the Arctic Weather and Climate Extremes 30 https://doi.org/ 10.1016/j.wace. 2020.100275

Overland JE, Ballinger TJ, Cohen J, Francis JA, Hanna E, Jaiser R et al (2021) How do intermittency and simultaneous processes obfuscate the Arctic influence on midlatitude winter extreme weather events? Environ Res Lett 16(4):043002. https://doi.org/10.1088/1748-9326/abdb5d

Rinke A, Maturilli M, Graham RM, Matthes H, Handorf D, Cohen L et al (2017) Extreme cyclone events in the Arctic: wintertime variability and trends. Environ Res Lett 12:094006. https://doi.org/10.1088/ 1748-9326/aa7def

Rolph RJ, Mahoney AR, Walsh J, Loring PA (2018) Impacts of a lengthening open water season on Alaskan coastal communities: deriving locally relevant indices from large-scale datasets and community observations. Cryosphere 12:1779-1790

Romanovsky VE, Smith SL, Isaksen K, Nyland KE, Kholodov AL, Shiklomanov NI, et al (2020) Terrestrial permafrost. In: Blunden J, Arndt DS (eds) State of the climate in 2019. Bull Am Meteorol Soc 101(8):S265-S269. https://doi.org/10.1175/BAMS-D-20-0086.1

Schweiger AJ, Wood KR, Zhang J (2019) Arctic sea ice volume variability over 1901-2010: A model-based reconstruction. J Clim 32:4731-4752. https://doi.org/10.1175/JCLI-D-19-0008.1

Schweiger AJ, Steele M, Zhang J et al (2021) Accelerated sea ice loss in the Wandel Sea points to a change in the Arctic's Last Ice Area. Commun Earth Environ 2:122. https://doi.org/10.1038/ s43247-021-00197-5

Shortridge J, Guikema S, Zaitchik B (2017) Robust decision making in data scarce contexts: addressing data and model limitations for infrastructure planning under transient climate change. Clim Change 140(2):323-337

Smith DM, Scaife AA, Eade R, Athanasiadis P, Bellucci A, Bethke I et al (2020) North Atlantic climate far more predictable than models imply. Nature 583:796-800. https://doi.org/10.1038/s41586-020-2525-0

Stabeno PJ, Bell SW (2019) Extreme conditions in the Bering Sea (2017-2018): record-breaking low seaice extent. Geophys Res Lett 46:8952-8959. https://doi.org/10.1029/2019GL083816

Tachibana Y, Komatsu KK, Alexeev VA, Cai L, Ando Y (2019) Warm hole in Pacific Arctic sea ice cover forced mid-latitude Northern Hemisphere cooling during winter 2017-18. Sci Rep 9:5567. https://doi. org/10.1038/s41598-019-41682-4

Tedesco M, Fettweis X (2020) Unprecedented atmospheric conditions (1948-2019) drive the 2019 exceptional melting season over the Greenland ice sheet. Cryosphere 14(4):1209-1223. https://doi.org/10. 5194/tc-14-1209-2020 
Thoman RL, Bhatt US, Bieniek PA, Brettschneider BR, Brubaker M, Danielson SL et al (2020) The record low Bering Sea ice extent in 2018: context, impacts, and assessment of the role of anthropogenic climate change. Bull Am Meteorol Soc 101(1):S53-S58. https://doi.org/10.1175/BAMS-D-19-0175.1

Thoman R, Walsh JE (2019) Alaska's changing environment 2019: Documenting Alaska's physical and biological changes through observations. International Arctic Research Center. University of Alaska, Fairbanks. https://uaf-iarc.org/our-work/alaskas-changing-environment/. Accessed 2021

Villamil-Otero GA, Zhang J, He J, Zhang X (2018) Role of extratropical cyclones in the recently observed increase in poleward moisture transport into the Arctic Ocean. Adv Atmos Sci 35:85-94. https://doi. org/10.1007/s00376-017-7116-0

Walsh JE, Ballinger TJ, Euskirchen ES, Hanna E, Mård J, Overland JE et al (2020) Extreme weather and climate events in northern areas: A review. Earth-Sci Rev 209:103324. https://doi.org/10.1016/j.earsc irev.2020.103324

Wang M, Yang Q, Overland JE, Stabeno PJ (2018) Sea-ice cover timing in the Pacific Arctic: The present and projections to mid-century by selected CMIP5 models. Deep-Sea Res Part II 152:22-34. https:// doi.org/10.1016/j.dsr2.2017.11.017

Woollings T, Barnes E, Hoskins B, Kwon Y-O, Lee RW, Li C et al (2018) Daily to decadal modulation of jet variability. J Clim 31:1297-1314. https://doi.org/10.1175/JCLI-D-17-0286.1

Publisher's note Springer Nature remains neutral with regard to jurisdictional claims in published maps and institutional affiliations. 